\title{
PROFIL KEMAMPUAN KONEKSI MATEMATIS MAHASISWA DALAM MENYELESAIKAN MASALAH PADA MATA KULIAH KALKULUS I DITINJAU BERDASARKAN LEVEL KEMAMPUAN AKADEMIK
}

\author{
Rezi Ariawan ${ }^{1)}$, Hayatun Nufus ${ }^{2)}$ \\ 1) Pendidikan Matematika, Universitas Islam Riau \\ 2) Pendidikan Matematika, Universitas Islam Negeri Sultan Syarif Kasim Riau \\ Email : reziariawan@edu.uir.ac.id
}

\begin{abstract}
Abstrak. Penelitian ini bertujuan untuk mendeskripsikan profil kemampuan koneksi matematis mahasiswa dalam menyelesaikan masalah pada mata kuliah kalkulus 1 ditinjau berdasarkan level kemampuan akademik. Penelitian ini merupakan penelitian kualitatif dengan subjek penelitian adalah mahasiswa pendidikan matematika FKIP UIR yang sudah lulus mata kuliah kalkulus 1 . Instrumen pengumpulan data terdiri dari lembar tes tertulis kemampuan koneksi matematis dan lembar pedoman wawancara. Analisis data dilakukan dengan menganalisis data tertulis dan hasil wawancara yang kemudian selanjutnya dilakukan triangulasi metode untuk mendapatkan data subjek penelitian yang valid. Hasil penelitian menunjukkan bahwa subjek pada level kemampuan tinggi dan rendah sudah mampu memahami dan menerapkan konsep matematika dibidang ilmu lainnya, sedangkan subjek pada level kemampuan sedang, ada sebagian yang memiliki kemampuan memahami dan menggunakan koneksi antar konsep matematika dengan bidang ilmu lainnya. Selanjutnya, subjek pada semua level kemampuan akademik belum mampu memahami dan menerapkan antar konsep matematika dan menerapkan konsep matematika dalam permasalahan sehari-hari.
\end{abstract}

Kata Kunci: Kemampuan Koneksi Matematis, Kalkulus 1, Level Kemampuan Akademik

\section{PENDAHULUAN}

Pembelajaran matematika di perguruan tinggi mempunyai peranan yang sangat penting dalam mengembangkan kemampuan berpikir, memecahkan masalah dan kemandirian belajar. Koko Martono (1990) menjelaskan bahwa tujuan pembelajaran matematika diperguruan tinggi adalah untuk memperoleh pengetahuan dasar dan pola pikir matematika dalam bentuk: (1) tertatanya pola pikir ilmiah yang kritis, logis, dan sistematis; (2) terlatihnya daya nalar dan kreativitas setelah mempelajari berbagai strategi dan taktik dalam pemecahan masalah kalkulus; (3) terlatih dalam merancang model matematika sederhana; (4) terampil dalam teknik matematika yang baku dengan didukung oleh konsep, penalaran, rumus, dan metode yang benar.

Kemampuan koneksi matematis sangat diperlukan sejak dini oleh setiap peserta didik termasuk di dalamnya mahasiswa. Menurut NCTM (2000) Koneksi matematis merupakan salah satu hal penting dalam berpikir matematis dan dapat membangun pemahaman matematis. Tanpa koneksi, mahasiswa harus mempelajari dan mengingat terlalu banyak konsep dan keterampilan. Dengan koneksi, mereka dapat membangun pemahaman baru dari pengetahuan sebelumnya. Hal ini karena melalui koneksi matematis maka pandangan dan pengetahuan mereka akan semakin luas terhadap matematika sebab semua yang terjadi di kehidupan sehari-hari maupun materi yang dipelajari saling berhubungan. Melalui koneksi pula, konsep pemikiran dan wawasan mahasiswa akan semakin terbuka dan luas terhadap matematika karena mereka akan memandang matematika sebagai suatu bagian yang terintegrasi bukan sebagai sekumpulan topik yang terpisah-pisah, serta mengakui adanya keterkaitan atau hubungan dan aplikasi di dalam kehidupan atau lingkungan sekitar mereka. Karena topik-topik dalam matematika banyak memiliki relevansi dengan disiplin ilmu lain, baik di kelas maupun di luar kelas.

Hal ini sejalan dengan apa yang dikemukakan Utari Sumarmo (2013), yang menyatakan dalam belajar matematika mahasiswa dituntut memahami koneksi antara ide-ide matematis dan antar matematika dan bidang studi lainnya karena topik-topik dalam matematika banyak memiliki relevansi dan manfaat dengan bidang lain, baik di sekolah maupun di luar sekolah. Jika mereka sudah mampu melakukan koneksi antara beberapa ide matematis, maka mereka akan memahami setiap materi matematika dengan lebih dalam dan baik. Selain itu, melalui koneksi konsep pemikiran dan wawasan mahasiswa akan semakin terbuka dan luas terhadap matematika karena mereka akan memandang matematika sebagai suatu bagian 
PRINSIP Pendidikan Matematika

Volume 1, Nomor 1, November 2018

yang terintegrasi bukan sebagai sekumpulan topik yang terpisah-pisah, serta mengakui adanya keterkaitan atau hubungan dan aplikasi di dalam kehidupan atau lingkungan sekitar mereka.

Selanjutnya, karena salah satu materi yang sering memiliki koneksi (baik koneksi antar topik matematika maupun dengan bidang lain serta kehidupan sehari-hari) adalah materi kalkulus diferensial (kalkulus I), maka perlu diteliti kemampuan koneksi matematis pada materi kalkulus diferensial (kalkulus I) dan untuk dapat mewujudkan penguasaan konsep mahasiswa yang baik terhadap kalkulus 1.

Dalam melakukan suatu koneksi matematis, tentu sangat dipengaruhi oleh kecerdasan. Berbicara tentang kecerdasan, tingkat kecerdasan mahasiswa beragam, ada yang pandai, sedang-sedang saja, dan lemah. Hal ini didukung oleh Galton (Ruseffendi, 2006) yang mengemukakan bahwa dari sekelompok mahasiswa yang dipilih secara sebarang (tidak dipilih secara khusus), akan dijumpai mahasiswa yang berkemampuan tinggi, sedang, dan rendah yang menyebar secara berdistribusi normal. Oleh karena itu, kelompok mahasiswa yang tergabung ke dalam level kemampuan matematis mahasiswa perlu mendapatkan kajian yang serius.

Berdasarkan latar belakang dan pentingnya masalah yang telah dikemukan di atas, maka masalah yang dikaji dalam penelitian ini adalah: (1) Bagaimanakah profil kemampuan koneksi matematis mahasiswa dalam menyelesaikan masalah pada mata kuliah kalkulus 1 ditinjau berdasarkan level kemampuan akademik (tinggi, sedang, rendah)?

\section{METODE}

Penelitian ini merupakan penelitian kualitatif. Menurut Lexy J. Moleong (2014) penelititian kualitatif mempunyai ciri-ciri: (1) mempunyai latar alami; (2) peneliti sebagai instrumen utama; (3) menggunakan metode kualitatif; (4) analisis data secara induktif; (5) teori dari dasar (grounded theory); (6) bersifat deskriptif; (7) lebih mementingkan proses daripada hasil; (8) adanya batas yang ditentukan oleh fokus penelitian; (9) adanya kriteria untuk keabsahan data; (10) desain penelitian bersifat sementara; dan (11) hasil penelitian dirundingkan dan disepakati bersama.

Senanda dengan pendapat di atas, Bogdan dan Biklen dalam Emzir (2012) menyatakan bahwa terdapat lima ciri utama penelitian kualitatif, yaitu; (1) naturalistik: memiliki latar aktual sebagai sumber langsung data dan peneliti merupakan instrumen kunci; (2) data deskriptif: data yang dikumpulkan lebih mengambil bentuk kata-kata atau gambar-gambar daripada angka-angka; (3) berurusan dengan proses: penelitian kualitatif lebih menekankan kepada proses daripada hasil atau produk; (4) induktif: penelitian kualitatif cenderung menganalisis data secara induktif, dan tidak melakukan pencarian di luar data atau bukti untuk menolak sebuah hipotesis.

Berdasarkan beberapa pendapat di atas , maka pendekatan penelitian ini adalah penelitian kualitatif. Disebut penelitian kualitatif karena prosedur penelitiannya menghasilkan data deskriptif berupa katakata tertulis atau lisan dari orang-orang atau tentang perilaku yang diamati.

Subjek dalam penelitian ini adalah mahasiswa semester 2 Program Sudi Pendidikan Matematika FKIP UIR semester genap yang sedang menempuh mata kuliah kalkulus 2 dengan peneliti sebagai dosennya yang berjumlah 33 orang. Pemilihan subjek penelitian ini didasari oleh beberapa pertimbangan, yaitu: (a) mahasiswa semester 2 yang sedang belajar kalkulus 2 dengan peneliti sudah mendapatkan mata kuliah kalkulus 1; (b) mudah diwawancarai sehingga akan diperoleh data akurat yang dibutuhkan dalam penelitian ini.

Untuk mendapatkan data tentang kemampuan subjek dalam menyatakan pendapat, ide, dan gagasan secara tulisan dengan jelas, maka peneliti membutuhkan instrumen bantu berupa tes kemampuan koneksi matematis, yang pada akhirnya dinyatakan oleh peneliti sebagai instrumen pertama. Berikut akan disajikan hasil validasi dan ujicoba lapangan terhadap instrumen bantu pertama.

Tabel 1. Rekapitulasi Kevalidan Soal Tes Kemampuan Koneksi Matematis

\begin{tabular}{ccc}
\hline $\begin{array}{c}\text { No. } \\
\text { Soal }\end{array}$ & $\begin{array}{c}\text { \% Nilai } \\
\text { Rata- } \\
\text { Rata }\end{array}$ & Kategori Kevalidan \\
\hline 1 & 97,29 & $\begin{array}{c}\text { Sangat valid, atau dapat digunakan } \\
\text { tanpa revisi }\end{array}$ \\
2 & 97,27 & $\begin{array}{c}\text { Sangat valid, atau dapat digunakan } \\
\text { tanpa revisi }\end{array}$ \\
3 & 100 & $\begin{array}{c}\text { Sangat valid, atau dapat digunakan } \\
\text { tanpa revisi }\end{array}$ \\
4 & 100 & $\begin{array}{c}\text { Sangat valid, atau dapat digunakan } \\
\text { tanpa revisi }\end{array}$ \\
5 & 96,36 & $\begin{array}{c}\text { Sangat valid, atau dapat digunakan } \\
\text { tanpa revisi }\end{array}$ \\
6 & 100 & $\begin{array}{c}\text { Sangat valid, atau dapat digunakan } \\
\text { tanpa revisi }\end{array}$ \\
\hline
\end{tabular}

Sumber: Data Olahan Peneliti 
PRINSIP Pendidikan Matematika

Volume 1, Nomor 1, November 2018

Tabel 2. Rekapitulasi Hasil Uji Coba Instrumen Pertama

\begin{tabular}{|c|c|c|c|c|c|}
\hline $\begin{array}{l}\text { No } \\
\text { Soal }\end{array}$ & $\begin{array}{l}\text { Interpretasi } \\
\text { Validitas }\end{array}$ & $\begin{array}{l}\text { Interpretasi } \\
\text { Daya } \\
\text { Pembeda }\end{array}$ & $\begin{array}{l}\text { Interpretasi } \\
\text { Tingkat } \\
\text { Kesukaran }\end{array}$ & Keterangan & Perlakuan \\
\hline 1 & $\begin{array}{l}0,535 \\
\text { (Cukup) }\end{array}$ & $\begin{array}{l}0,17 \\
\text { (Jelek) }\end{array}$ & $\begin{array}{l}0,75 \\
\text { (Mudah) }\end{array}$ & $\begin{array}{l}\text { Tidak } \\
\text { Layak }\end{array}$ & $\begin{array}{l}\text { Tidak } \\
\text { digunakan }\end{array}$ \\
\hline 2 & $\begin{array}{l}0,640 \\
\text { (Tinggi) }\end{array}$ & $\begin{array}{l}0,25 \\
\text { (Cukup) }\end{array}$ & $\begin{array}{l}0,48 \\
\text { (Sedang) }\end{array}$ & Layak & $\begin{array}{l}\text { Digunakan } \\
\text { dengan } \\
\text { perbaikan }\end{array}$ \\
\hline 3 & $\begin{array}{l}0,644 \\
\text { (Cukup) }\end{array}$ & $\begin{array}{l}0,21 \\
\text { (Jelek) }\end{array}$ & $\begin{array}{l}0,81 \\
\text { (Mudah) }\end{array}$ & $\begin{array}{l}\text { Tidak } \\
\text { Layak }\end{array}$ & $\begin{array}{l}\text { Tidak } \\
\text { digunakan }\end{array}$ \\
\hline 4 & $\begin{array}{l}0,580 \\
\text { (Cukup) }\end{array}$ & $\begin{array}{l}0,23 \\
\text { (Cukup) }\end{array}$ & $\begin{array}{l}0,73 \\
\text { (Mudah) }\end{array}$ & Layak & $\begin{array}{l}\text { Digunakan } \\
\text { dengan } \\
\text { perbaikan }\end{array}$ \\
\hline 5 & $\begin{array}{l}0,574 \\
\text { (Cukup) }\end{array}$ & $\begin{array}{l}0,21 \\
\text { (Jelek) }\end{array}$ & $\begin{array}{l}0,15 \\
\text { (Sukar) }\end{array}$ & $\begin{array}{l}\text { Tidak } \\
\text { Layak }\end{array}$ & $\begin{array}{l}\text { Tidak } \\
\text { digunakan }\end{array}$ \\
\hline 6 & $\begin{array}{l}0,467 \\
\text { (Cukup) }\end{array}$ & $\begin{array}{l}0,21 \\
\text { (Jelek) }\end{array}$ & $\begin{array}{l}0,64 \\
\text { (Sedang) }\end{array}$ & Layak & $\begin{array}{l}\text { Digunakan } \\
\text { dengan } \\
\text { perbaikan }\end{array}$ \\
\hline
\end{tabular}

\section{Sumber: Data Olahan Peneliti}

Dengan memperhatikan tabel di atas, maka peneliti memutuskan untuk menggunakan 3 soal yaitu soal nomor 2, 4, dan 6 yang merupakan keterwakilan dari masing-masing indikator yang sudah ditentukan.

Sedangkan untuk mendapatkan data berupa kemampuan subjek dalam menyatakan ide, gagasan dan pendapat secara lisan dengan jelas, maka peneliti membutuhkan lembar wawancara, yang pada akhirnya peneliti namakan sebagai instrumen bantu kedua.

Analisis data dilakukan berdasarkan data tes tertulis dan data hasil wawancara. Data yang telah terkumpul dianalisis dengan langkah-langkah: (1) Reduksi data yakni melakukan proses pemilihan, penyederhanaan, dan transformasi data di lapangan. Dalam proses ini peneliti melakukan pemilihan subjek berdasarkan level kemampuan akademik dengan kriteria pembagian kelompok sebagai berikut.

Tabel 3. Kriteria Pembagian Kelompok Level Kemampuan Akademik

\begin{tabular}{cc}
\hline Level Kemampuan & Rentang Nilai \\
\hline Tinggi & $x \geq \bar{x}+\sigma$ \\
Sedang & $\bar{x}-\sigma<x<\bar{x}+\sigma$ \\
Rendah & $x \leq \bar{x}-\sigma$ \\
\hline
\end{tabular}

Sumber: Modifikasi dari Rezi Ariawan (2013)

Keterangan:

$x=$ skor kemampuan koneksi matematis masing-

masing mahasiswa

$\bar{x}=$ rata-rata skor kemampuan koneksi matematis

mahasiswa

$\sigma=$ simpangan baku skor kemampuan koneksi

matematis mahasiswa

Selanjutnya kejelasan dalam tulisan yang selanjutnya akan dilakukan wawancara; (2) Pemaparan data yakni pengklasifikasian dan mengidentifikasi data sehingga terorganisir dan terkategori dengan baik.
Dalam hal ini peneliti melakukan telaah terhadap hasil tes tertulis, hasil wawancara berdasarkan gaya kognitif yang sudah ditentukan; (3) Menarik kesimpulan berdasarkan hasil paparan data. Dalam hal ini peneliti melakukan triangulasi metode untuk mendapatkan data subjek yang valid.

\section{HASIL DAN PEMBAHASAN}

Penentuan subjek berdasarkan level kemampuan akademik dilakukan dengan beberapa langkah, diantaranya yaitu: (1) Peneliti melakukan diskusi dan meminta nilai akhir mata kuliah kalkulus 1 kepada salah seorang dosen pendidikan matematika yang nantinya akan peneliti gunakan sebagai data awal untuk mengelompokkan mahasiswa berdasarkan level kemampuan akademik mahasiswa. Data awal tentang nilai akhir mahasiswa pada mata kuliah kalkulus 1 diperlukan untuk mengelompokkan mahasiswa berdasarkan level kemampuan akademik. Berdasarkan data yang diperoleh, banyaknya jumlah mahasiswa berdasarkan level kemampuan akademik dapat dilihat pada tabel di bawah ini.

Tabel 4. Jumlah Mahasiswa Berdasarkan Level Kemampuan Akademik

\begin{tabular}{ccc}
\hline $\begin{array}{c}\text { Level } \\
\text { Kemampuan }\end{array}$ & $\begin{array}{c}\text { Jumlah } \\
\text { Mahasiswa }\end{array}$ & Persentase \\
\hline Tinggi & 7 Orang & $15,9 \%$ \\
Sedang & 29 Orang & $65,9 \%$ \\
Rendah & 8 Orang & $18,2 \%$ \\
\hline
\end{tabular}

Sumber: Data Olahan Peneliti

(2) Selanjutnya seluruh subjek penelitian diberikan instrumen bantu pertama berupa tes tertulis yang memuat butir soal kemampuan koneksi matematis. Berdasarkan data yang peneliti peroleh berupa jawaban subjek penelitian terhadap butir soal tersebut, peneliti memilih subjek penelitian yang memenuhi kriteria yang sudah ditetapkan yaitu kejelasan dalam menyampaikan ide melalui tulisannya. Berikut hasil rekapitulasinya:

Tabel 5. Rekapitulasi Rata-Rata Skor Kemampuan Koneksi Matematis Mahasiswa Ditinjau Berdasarkan Keseluruhan dan Level Kemampuan Akademik

\begin{tabular}{|c|c|c|c|c|}
\hline \multirow{2}{*}{$\begin{array}{c}\text { Level } \\
\text { Kemampuan } \\
\text { Akademik }\end{array}$} & \multicolumn{3}{|c|}{ Rata-Rata Soal } & \multirow{2}{*}{$\begin{array}{c}\text { Rata-Rata } \\
\text { Setiap Level } \\
\text { Kemampuan } \\
\text { Akademik }\end{array}$} \\
\hline & 1 & 2 & 3 & \\
\hline Tinggi & 2 & 3 & 1 & 2 \\
\hline Seda & 0,96 & 2,76 & 0,28 & 1,33 \\
\hline Rendah & 0,5 & 3,5 & 0 & 1,33 \\
\hline $\begin{array}{l}\text { Rata-Rata } \\
\text { Keseluruha }\end{array}$ & 1,03 & 2,87 & 0,33 & 1,41 \\
\hline
\end{tabular}

Sumber: Data Olahan Peneliti 
Berdasarkan tabel di atas, terlihat bahwa untuk level kemampuan sedang dan rendah secara keseluruhan memiliki rata-rata yang sama. Subjek penelitian pada level kemampuan akademik rendah memiliki rata-rata sama dengan 0 , ini artinya tidak ada satupun subjek dari level kemampuan akademik rendah yang mampu menjawab soal nomor 3. Dari ketiga soal, soal monor 2 yang rata-ratanya paling tinggi, ini menandakan bahwa sebagian besar subjek penelitian mampu menyelesaikan soal ini dengan benar. (3) Penentuan subjek penelitian yang memenuhi kriteria berikutnya, peneliti lakukan dengan memperhatikan kejelasan dan kemampuan subjek penelitian tersebut dalam menyampaikan ide, pendapat dan gagasan. Untuk mendapatkan informasi ini, peneliti lakukan observasi selama subjek penelitian melakukan perkuliahan Kalkulus 2 dengan peneliti sebagai dosen pengampu mata kuliah tersebut. (4) Berdasarkan langkah 2 dan 3, maka peneliti menetapkan subjek yang dipilih adalah sebanyak 3 orang yang merupakan keterwakilan dari setiap level kemampuan akademik. (5) langkah selanjutnya subjek yang mememnuhi kriteria akan peneliti wawancara dengan menggunakan instrumen bantu kedua. Berikut akan disajikan data subjek yang memenuhi kriteria sebagai subjek penelitian berdasarkan level kemampuan akademik

Tabel 6. Mahasiswa yang Memenuhi KriteriaSubjek Penelitian Berdasarkan Level Kemampuan Akademik

\begin{tabular}{|c|c|c|c|c|c|c|}
\hline \multirow{2}{*}{ No } & \multirow{2}{*}{ Nama } & \multirow{2}{*}{ NPM } & \multirow{2}{*}{ LPP } & \multicolumn{2}{|c|}{$\begin{array}{c}\text { Mengemukakan } \\
\text { Pendapat }\end{array}$} & \multirow{2}{*}{$\begin{array}{c}\text { Level } \\
\text { Kemampuan }\end{array}$} \\
\hline & & & & Tulisan & Lisan & \\
\hline 1 & $\mathrm{SM}$ & 16411047 & $\mathrm{P}$ & Jelas & Jelas & Tinggi \\
\hline 2 & $\mathrm{ZM}$ & 16411034 & $\mathrm{P}$ & Jelas & Jelas & Tinggi \\
\hline 3 & $\mathrm{FI}$ & 16411057 & $\mathrm{~L}$ & Jelas & Jelas & Tinggi \\
\hline 4 & $\mathrm{KJ}$ & 16411132 & $\mathrm{P}$ & Tidak Jelas & $\begin{array}{l}\text { Kurang } \\
\text { Jelas }\end{array}$ & Sedang \\
\hline 5 & AR & 16411193 & $\mathrm{P}$ & Tidak Jelas & $\begin{array}{l}\text { Kurang } \\
\text { Jelas }\end{array}$ & Sedang \\
\hline 6 & TQ & 16411007 & $\mathrm{P}$ & Jelas & $\begin{array}{l}\text { Kurang } \\
\text { Jelas }\end{array}$ & Sedang \\
\hline 7 & $\mathrm{AR}$ & 16411157 & $\mathrm{P}$ & Jelas & $\begin{array}{l}\text { Kurang } \\
\text { Jelas }\end{array}$ & Rendah \\
\hline 8 & NO & 16411248 & $\mathrm{P}$ & Tidak Jelas & $\begin{array}{l}\text { Kurang } \\
\text { Jelas }\end{array}$ & Rendah \\
\hline 9 & WE & 16411187 & $\mathrm{P}$ & Jelas & Jelas & Rendah \\
\hline
\end{tabular}

Sumber: Data Olahan Peneliti

Dari informasi pada tabel di atas, maka seluruh subjek penelitian tersebut yang akan peneliti lakukan penelitian lanjutan, dimana seluruh subjek tersebut yang peneliti wawancara. Setelah proses wawancara selesai dilakukan, peneliti melakukan analisis terhadap hasil tes kemampuan koneksi matematis subjek penelitian.
Selanjutnya peneliti melakukan wawancara dengan subjek penelitian. Informasi yang peneliti peroleh dari hasil tes tertulis dan dari hasil wawancara dengan subjek penelitian, kemudian peneliti lakukan triangulasi data. Berikut akan dipaparkan hasil triangulasi datanya.

Berdasarkan tiga indikator kemampuan koneksi matematis yang peneliti gunakan dalam penelitian ini yaitu: (1) Kemampuan memahami dan menggunakan koneksi di antara topik-topik matematika; (2) Kemampuan menerapkan matematika dalam bidang lain; (3) Kemampuan menerapkan matematika dalam kehidupan sehari-hari, subjek penelitian yang berada pada level kemampuan akademik tinggi belum menguasai kemampuan pada indikator 1 , dan 3 . Sedangkan untuk indikator 2 , subjek penelitian ada yang sudah menguasai dan ada yang belum menguasai kemampuan tersebut.

Untuk indikator 1, subjek penelitian pada level kemampuan akademik tinggi sudah menyatakan sebagian konsep yang dibutuhkan dengan benar, tetapi konsep yang dinyatakan tidak dapat digunakan dengan baik untuk menyelesaikan permasalahan yang diberikan. Subjek penelitian pada level kemampuan akademik tinggi mencoba menemukan panjang masing-masing kawat, ada yang dengan langsung membagi panjang kawat menjadi dua bagian yang sama panjang dan ada yang dengan menggunakan inisiatif pembagian dengan alasan banyak sisi dari masingmasing bangun datar yang dibentuk. Secara garis besar, subjek penelitian sudah pada level kemampuan akademik tinggi sudah memberikan respon walaupun selesaian akhir yang diberikan masih belum benar.

Sedangkan subjek penelitian pada level kemampuan akademik sedang, untuk indikator 1 sudah mencoba memberikan respon dengan menyatakan konsep yang digunakan, tetapi konsep yang dinyatakan masih salah. Ada pula subjek penelitian pada level kemampuan sedang yang tidak menyatakan bahwa konsep yang dibutuhkan apa, dengan alasan belum mengenal dan memahami tentang apa saja konsep yang akan digunakan. Walaupun demikian, subjek pada level kemampuan sedang sudah sedikit lebih bervariasi dalam proses untuk menyatakan panjang masing-masing kawat. Misalnya ada subjek penelitian pada level kemampuan sedang yang menyatakan bahwa untuk mendapatkan panjang masing-masing kawat harus melakukan pemisalan yaitu dimisalkan panjang kawat pertama adalah $x \mathrm{~cm}$ dan panjang kawat kedua adalah $16-x \mathrm{~cm}$. Apa yang sudah dinyatakan oleh salah satu subjek penelitian pada level kemampuan akademik sedang jah lebih maju jika dibandingankan dengan subjek penelitian pada level kemampuan tinggi. Walaupun pada akhirnya subjek penelitian pada level 
kemampuan akademik sedang tersebut tidak dapat mengeksekusi pemisalan tersebut sampai menemukan selesaian akhir dengan benar.

Selanjutnya subjek penelitian pada level kemampuan rendah, dalam menyelesaikan permasalahan 1 yang merupakan perwakilan dari indikator 1 kemampuan koneksi matematis langsung membagi panjang kawat menjadi dua bagian yang sama panjang. Selanjutnya subjek penelitian pada levek kemampuan akademik rendah juga ada menyatakan konsep tetapi konsep yang dinyatakan masih salah, misalnya konsep luas segitiga sama sisi. Subjek penelitian pada level kemampuan akademik rendah menyatakan rumus luas segitiga sama sisi adalah $s x s x$ $s$ seharusnya rumus luas segitiga itu adalah $1 / 2 x$ a $x \mathrm{t}$.

Secara keseluruhan semua subjek pada semua level kemampuan akademik (tinggi, sedang, rendah) belum memiliki kemampuan untuk memahami dan menerapkan konsep antar matematika. Walaupun demikian, masing-masing subjek penelitian pada masing-masing level kemampuan menunjukkan perbedaan kualitas kekeliruan yang dilakukan.

Untuk indikator 2, subjek penelitian pada level kemampuan akademik tinggi dan rendah, sama-sama sudah mampu memahami permasalahan yang diberikan dan memberikan selesaian akhir dengan benar. Hal ini bertolak belakang dengan apa yang terjadi pada subjek penelitian pada level kemampuan akademik sedang. Subjek penelitian pada level kemampuan akademik sedang, ada yang sudah memberikan selesaian terhadap permasalahan yang merupakan perwakilan dari indikator 2 dengan benar, dan ada juga subjek penelitian pada level kemampuan akademik sedang yang belum memberikan selesaian dengan benar. Subjek penelitian pada level kemampuan akademik sedang, yang belum memberikan selesaian dengan benar, subjek penelitian tersebut tidak memberikan respon sama sekali dengan alasan tidak bisa mengerjakan jika tidak lihat buku. Hal ini bisa saja terjadi, karena menurut peneliti adanya perbedaan dalam penentuan level kemampuan akademik. Dimana level kemampuan akademik peneliti lakukan berdasarkan informasi nilai yang diperoleh mahasiswa pada mata kuliah kalkulus1, dimana nilai tersebut merupakan gabungan dari semua materi dari kalkulus 1, misalnya ada materi fungsi, limit, dan turunan. Sedangkan pada penelitian ini kajian penelitian, peneliti fokuskan pada aplikasi turunan. Kemungkinan bisa jadi subjek penelitian pada level kemampuan akademik sedang kurang menguasai konsep turunan.

Pada indikator 3, semua subjek penelitian pada semua level kemampuan akademik (tinggi, sedang, dan rendah) belum mampu menerapkan konsep matematika dalam permasalahan sehari-hari. Subjek penelitian pada

level kemampuan akademik tinggi ada yang tidak memberikan respon terhadap permasalahan yang diberikan. Ada juga subjek pada level kemampuan akademik tinggi yang hanya menyatakan apa saja yang diketahui, tidak sampai menyatakan konsep apa saja yang dinyatakan. Untuk subjek penelitian pada level kemampuan akademik sedang, pada permasalahan yang diberikan sama sekali tidak memberikan respon. Sedangkan untuk subjek penelitian pada level kemampuan akademik rendah, sama sekali tidak memberikan respon.

Apa yang dilakukan oleh subjek penelitian pada permasalahan yang merupakan perwakilan dari indikator 3, mengindikasikan bahwa permasalahan yang diberikan tergolong dalam kategori sangat sukar, padahal dari hasil ujicoba soal, soal nomor 3 yang merupakan perwakilan dari indikator 3 bukanlah tergolong dalam kategori sangat sukar, melainkan sedang. Hal ini diperkuat oleh pernyataan dari salah seorang subjek penelitian yang menyatakan bahwa soal nomor 3 tersebut sangat sukar serta ada juga yang menyatakan belum dipelajari dikalkulus 1 . Sedangkan untuk permasalahan 1 yang diberikan, ada juga subjek yang menyatakan bahwa permasalahan yang diberikan belum dipelajari dikalkulus 1. Apabila informasi yang disampaikan oleh subjek penelitian tersebut benar, maka perlu diadakan pembaharuan dalam pembelajaran kalkulus 1, terutama dalam pengembangan kompetensi yang harus dikuasai oleh mahasiswa.

Tabel 7. Rekapitulasi Data Subjek yang Valid Berdasarkan Level Kemampuan Akademik

\begin{tabular}{|c|c|}
\hline Level & Data Subjek yang Valid \\
\hline Tinggi & $\begin{array}{l}\text { 1. Semua subjek belum memiliki } \\
\text { kemampuan memahami dan } \\
\text { menggunakan koneksi antar konsep } \\
\text { matematika. } \\
\text { 2. Semua subjek sudah memiliki } \\
\text { kemampuan untuk menerapkan konsep } \\
\text { matematika dengan bidang ilmu } \\
\text { lainnya. } \\
\text { 3. Semua subjek belum memiliki } \\
\text { kemampuan untuk menerapkan dan } \\
\text { menggunakan konsep matematika } \\
\text { dengan dunia nyata. }\end{array}$ \\
\hline Sedang & $\begin{array}{l}\text { 1. Semua subjek belum memiliki } \\
\text { kemampuan memahami dan } \\
\text { menggunakan koneksi antar konsep } \\
\text { matematika. } \\
\text { 2. Ada subjek belum memiliki } \\
\text { kemampuan menerapkan konsep } \\
\text { matematika dengan bidang ilmu } \\
\text { lainnya, serta ada juga subjek yang }\end{array}$ \\
\hline
\end{tabular}


PRINSIP Pendidikan Matematika

Volume 1, Nomor 1, November 2018

sudah memiliki kemampuan untuk menerapkan konsep matematika dengan bidang ilmu lainnya.

3. Semua subjek belum memiliki kemampuan untuk menerapkan dan menggunakan konsep matematika dengan dunia nyata.

1. Semua subjek belum memiliki kemampuan memahami dan menggunakan koneksi antar konsep matematika.

2. Semua subjek sudah memiliki kemampuan untuk menerapkan konsep

Rendah matematika dengan bidang ilmu lainnya.

3. Semua subjek belum memiliki kemampuan untuk menerapkan dan menggunakan konsep matematika dengan dunia nyata.

\section{Sumber: Data Olahan Peneliti}

Berdasarkan paparan di atas (tabel 6 dan 7), terlihat bahwa subjek pada level kemampuan tinggi, sedang dan rendah sama- sama sudah mampu mengkoneksikan konsep matematika dengan bidang ilmu lainnya. Sedangkan indikator kemampuan koneksi lainnya belum dapat diselesaikan dengan benar oleh subjek baik ditinjau berdasarkan level kemampuan akademik.

Jika dilihat berdasarkan kualitas soal yang merupakan keterwakilan dari setiap indikator kemampuan koneksi matematis, maka indikator kemampuan koneksi matematis yaitu kemampuan memahami dan menerapkan konsep matematika dengan konsep matematika lainnya yang diwakili oleh soal nomor 2 dan menggunakan konsep matematika pada dunia nyata, maka kedua soal tersebut memiliki indeks kesukaran dengan kategori sedang, sedangkan indikator kemampuan menggunakan konsep matematika dengan bidang ilmu lainnya yang diwakili oleh soal nomor 4 memiliki indeks kesukaran dengan kategori mudah. Berdasarkan paparan di atas, maka wajar subjek dapat menyelesaikan soal yang mewakili indikator kemampuan menggunkan konsep matematika dengan bidang ilmu lainnya dengan benar.

Untuk soal yang mewakili indikator kemampuan menggunakan konsep matematika dengan dunia nyata, subjek dengan level kemampuan sedang dan rendah sama sekali tindak memberikan respon, sedangkan subjek dengan kemampuan matematis tinggi memberikan respon tetapi masih salah. Untuk soal yang mewakili kemampuan memahami dan menggunakan konsep matematika dengan konsep matematika lainnya, subjek dari semua level kemampuan matematis memberikan respon, tetapi respon yang diberikan terdapat perbedaan. Subjek dengan level kemampuan tinggi, memberikan respon dengan mampu menyatakan sebagian konsep yang dibutuhkan dengan benar, tetapi masih salah dalam menyatakan alasan mengapa menyatakan sebagian konsep tersebut. Sedangkan subjek pada level kemampuan sedang dan rendah samasama memberikan respon, dimana subjek level kemampuan sedang dan rendah belum mampu menyatakan konsep apa saja yang dibutuhkan untuk menyelesaikan soal yang diberikan.

Intinya walaupun sama-sama belum memiliki kemampuan koneksi matematis pada indikator yang sudah dipaparkan di atas, tetapi subjek dari setiap level kemampuan matematis memiliki perbedaan.

\section{SIMPULAN}

Berdasarkan hasil penelitian dan pembahasan di atas, maka dapat disimpulkan bahwa subjek pada level kemampuan tinggi dan rendah sudah mampu memahami dan menerapkan konsep matematika dibidang ilmu lainnya, sedangkan subjek pada level kemampuan sedang, ada sebagian yang memiliki kemampuan memahami dan menggunakan koneksi antar konsep matematika dengan bidang ilmu lainnya. Selanjutnya, subjek pada semua level kemampuan akademik belum mampu memahami dan menerapkan antar konsep matematika dan menerapkan konsep matematika dalam permasalahan sehari-hari.

\section{DAFTAR PUSTAKA}

Emzir. (2012). Metodologi Penelitian Kualitatif (Analisis Data). Jakarta: Rajawali Pers.

Martono, K. (1999). Kalkulus. Jakarta: Erlangga.

Moleong, L.J. (2014). Metode Penelitian Kualitatif Edisi Revisi. Bandung: Rosdakarya.

National Council of Teachers of Mathematics (NCTM). (2000). Principles and standard for School Mathematics. Reston: NCTM.

Ariawan, R. (2013). Penerapan Pendekatan Pembelajaran Visual Thinking Disertai Aktivitas Quick On The Draw Untuk Meningkatkan Kemampuan Pemecahan Masalah dan Kemampuan Komunikasi Matematis Siswa. Tesis Pada Sekolah Pascasarjana UPI. Tesis Tidak Diterbitkan. 
PRINSIP Pendidikan Matematika

Volume 1, Nomor 1, November 2018

Ruseffendi, H. E. T. (2006). Pengantar kepada Membantu Guru Mengembangkan Kompetensinya dalam Pengajaran Matematika untuk Meningkatkan CBSA. Bandung: Tarsito.
Sumarmo, U. (2013). Kumpulan Makalah Berpikir dan Disposisi Matematik Serta Pembelajarannya. Bandung: UPI 